\title{
THE ROLE OF PUBLIC PARTICIPATION AND ENVIRONMENTAL ACTIVISM IN ENVIRONMENTAL GOVERNANCE IN LATVIA
}

\author{
Alda Ozola \\ University of Latvia, Faculty of Economics and Management \\ Department of Environmental Management \\ Raiņa boulevard 19, Rīga, LV 1586, Latvia; ph.: +(371) 29173047, e-mail: alda@lu.lv
}

\begin{abstract}
The paper discusses engagement of non-governmental organisations and activist groups in environmental governance in Latvia. The research is based on desk research, a number of case studies and action research. Author attempts to analyse to what extent environmental NGOs and groups of activists have contributed to environmental governance and what role public participation plays in that. Author concludes that identification of problematic issues and policy planning are those stages where public participation and activism in environmental governance plays most crucial role. Contrary to common public believe about informal groups and environmental activism only attempting to oppose any proposed projects or new developments, these groups can and do play and important role in environmental governance. Author also concludes that institutional system that supports public participation is crucial in facilitating public involvement in environmental governance. Author also suggests that participatory environmental governance can better meet challenges of sustainability.
\end{abstract}

Keywords: environmental activism, environmental governance, non-governmental organisations, public participation.

\section{Introduction}

There are multiple interpretations of environmental governance, but in broad terms it can be seen as attempts by governing bodies or combinations to alleviate recognized environmental dilemmas [1]. Unlike top-down decision making and enforcement in environmental protection, environmental governance involves a reallocation of power so that citizens and other civil society actors are involved in all aspects of the policy process from issue identification to implementation and monitoring [2].

In environmental governance there are several conceptual perspectives that have developed during the past several decades - one of it is pluralism. The approach of pluralism is guided by the premise that public policy is the outcome of competing interests and limited resources and that the appropriate role of state institutions is to provide fair framework within which these social decision-making processes play out [3]. Pluralism is an important approach also in contemporary environmental governance, particularly given the increasing emphasis on public participation in environmental policy making. It has been stressed by practitioners that citizens and organisations of civil society have become increasingly vocal, bringing forward issues and demands and trying to influence policy-makers [4]. The engagement of civil society actors, primarily non-government organisations (NGOs), has become an accepted aspect of environmental governance in democratic systems. Environmental governance promotes collaboration among diverse parties in order to develop creative and effective solutions to environmental problems and generate commitment to the outcomes that are achieved [2]. However there are two distinct visions about the role NGOs play i.e. on one hand NGOs are seen as representing public interests or certain group of people, while on the other hand they are also seen as partners to governmental institutions and working collaboratively with officials.

In countries where democratic institutions are weak, authorities fear that NGOs might take on too many responsibilities and their administrative power could exceed the one of government. 
For instance in recent crisis in Haiti authorities have pointed out to the situation where government was weak and unable to deliver appropriate services to the population whereas NGOs were very strong with lots of resources and thus in many communities NGOs exercise more political clout than government [5]. Thus there can be even situations when NGOs actually dominate in the governance.

Environmental NGOs and activist groups in Latvia play different roles if one considers approaches they use, working methods and activities and thus environmental NGOs can act either as watchdogs or partners or both. Here author sees public participation as somewhat institutionalised form of civic participation i.e. using opportunities provided by Latvian legislation and various institutions such as submitting comments to draft legislation, policy document or taking part in a public hearing meeting. However environmental activism is seen by author as a more pro-active form of activities and creating of new opportunities and approaches in environmental governance. Notwithstanding the focus on environmental governance of Latvia, author stresses that also broader picture of development of civil society and public participation traditions in Latvia should be considered.

\section{Materials and methods}

The paper attempts to review and analyse public participation activities of formally registered NGOs and civic initiative groups (activist groups) or activists that are involved in environmental issues and define their role in Latvian environmental governance. By officially registered NGOs author understands officially registered societies or foundations that are registered according to Associations and Foundations Law and whose aim (or one of aims) is related to environmental protection. By environmental activist groups author understands either so called NIMBY ("not-in-my-backyard") groups, who oppose certain investment projects that are seen as harmful to environment, public health or in other way negatively affecting the quality of life, or they can be civic initiative groups that aim to preserve certain natural habitats, natural resources etc. Author also aims to identify in which stages of environmental governance public involvement is most influential and with highest added value. It also reviews methods they use and looks to their interaction with other target groups such as public administration institutions, local governments and businesses.

Author uses desk research studying academic literature (academic books, journals, critical reviews), as well as applied literature such as handbooks, manuals, presentations from meetings, policy papers, reports, news articles and national legislation such as regulations, laws and international conventions. In empirical research the author uses interviews, casestudy research and action research methods to examine how NGOs are using participation opportunities secured by national legislation and whether institutional system promotes or hinders that. The author also attempts to analyse which participation methods environmental NGOs use, what are the key factors that determine and influence efficiency of public participation in environmental issues and environmental advocacy.

There are several limitations to methods applied that limit the scope of research to some extent. It has been difficult to use quantitative research data during research as for environmental NGOs, there is no separate register thus it is difficult to assess the number of NGOs that are involved in environmental issues. According to data from Lursoft data base, there are 12,441 societies and 889 foundations registered in Latvia [6], however it is not clear how many of those are dealing with environmental issues. When Ministry of Environment organised annual environmental forums, there were not more than 100 participants. The data about number of environmental NGOs is also not available at Civic Alliance - Latvia which "advocates the interests of Latvian non-governmental sector on the state level cooperating with ministries and inter-governmental councils and providing expertise and recommendations in the law-drafting process" [7]. Furthermore there is no register of 
informal action groups although they also play certain role in environmental governance. Thus author based analysis and discussion as well as conclusions on qualitative research methods i.e. case studies, interviews and professional knowledge connected to author's longterm engagement in activities of environmental NGOs.

\section{Results and discussion}

Public participation is often viewed as activities carried out by NGOs who attempt to influence policy processes at national or local level, but it can also be related to local inhabitants taking part in a public hearing meeting or writing a protest letter to their government. Thus when discussing public participation in environmental governance, one should first clarify terms and definitions. First of all it should be stressed that public participation doesn't imply participation of masses in decision making processes thus distinction should be made between "public at large" and "organised public". Organised public is seen to be composed of NGOs, associations and other types of civic groups who have certain aims and who use various methods in achieving those.

While doing research, author reviewed and explored deeper various concepts of NGOs, their interactions with other stakeholders and their potential role in national environmental governance. What are environmental NGOs and what is their constituency? Do only formally registered NGOs count or also informal groups composed of concerned people and activists should be seen as NGOs and stakeholders? Are those organisations to be seen as representatives of public or they are rather partners to public institutions and businesses? These are some of the research questions that author attempted to find answers to.

When defining ,the public", the Convention on Access to Information, Public Participation in Decision-making and Access to Justice in Environmental Matters (Aarhus convention) makes a reference to national legislation or practice mentioning that it may include one or more natural or legal persons, their associations, organisations or groups [8]. This however is also rather vague concept when it comes to explaining public participation and defining the place for NGOs in it. Another way of defining scope of NGOs is to talk about „the public concerned". According to Aarhus convention "the public concerned" involves:

- The public affected or likely to be affected by environmental decision-making,

- The public having an interest in environmental decision-making;

The Convention further explains that NGOs promoting environmental protection and meeting any requirements under national law shall be deemed to have an interest and thus should be also considered as "the public concerned".

National Environmental Protection Law stipulates that "The public has the right to participate in the taking of such decisions and the preparation of such planning documents, also the preparation of amendments therein, which may affect the environment. The public may implement this right before the relevant decision or document has been taken". The Law also specifies (Section 6) that "public" could be a private person, associations, organisations and groups of persons. Thus also activist groups are recognized as stakeholders that have right for participation in decision-making and decision-taking processes. Also looking from legal point of view, it has to be stressed that there are no criteria set for NGOs and no separate NGO recognition procedure introduced in the country, and there is no need for it [9]. National legislation in Latvia provides wide rights in access to environmental information, participation and legal protection.

The concept of governance in very general terms distinguish between governments (state), businesses (market) and civil society as three main categories of actors that interact with each other. However scholars emphasize that civil society should not be seen as a coherent group, but that it is comprised of non-state, non-economic actors. However when it comes to environmental governance, environmental policies and their implementation, scholars and 
researchers highlight NGOs as one of the key target groups. Some researchers point to NGOs as one of important groups that reflect public interests [10], NGOs as representatives of more active part of society, who is interested in involvement [11] or providing voice for marginalised populations and minority views [2]. State Chancellery of Latvia sees NGOs as representatives of the society who have joined together in NGOs to protect their interests and voice their opinion have better opportunities to influence the decision-making process [11]. However some scholars would stress the expertise of NGOs and their ability to be partners to national governments [2] thus NGOs can play various roles - being a watchdog, a partner or both.

It also has to be highlighted that environmental NGOs do not form a coherent group - they might have diverse or even conflicting approaches or methods in their activities. Some scholars point out to various clusters within NGO community i.e. that in the first cluster there are environmental NGOs that are highly professional and in other cluster is composed of NGOs that take action on behalf of their members and play role at the local level [2]. Another approach of categorising NGOs and activist groups is by looking at their tactics. There can be two tactical poles identified: success-oriented versus value-oriented NGOs. The first group of NGOs involves those organisations and activists who prioritise the achievement of specific aims, such as defeating a specific government plan or business proposition. However the latter group of value oriented NGOs are more interested in intentions and in the expressions of specific values and way of life thus here their aim often is to set a good example, to change values and people, than to restrict the actions of others [12].

All in all the results of desk research suggest that there should be careful distinction made between "public participation" and "NGO participation", because NGOs can play various roles and have various functions or identities. Although they might overlap, the author considers that NGO functions and those of activist groups can be categorised in following way:

- Representation: representing concerned public, groups or public at large; representing and defending interests of nature;

- Partnership: cooperating with public authorities and/or local governments in environmental governance, including awareness raising on environmental issues;

As for representation function it has to be considered that although NGOs are part of public, their involvement can't replace wider public participation, because each NGO has certain agenda that is connected to the goals of that specific NGO. Public participation measures should be broad enough in order to allow various interests to be represented, not only interests of certain groups [10].

The function of NGOs being partners is also often mentioned both in national legislation as well as national strategies. Latvian Environmental Policy strategy for 2009-2015 has to be considered as major policy document of national environmental governance. The strategy outlines that one of the principles integrated in the strategy is ,public information and participation principle", meaning that environmental institutions promote public education and information, listen to and evaluate public opinion. Similarly also other national legal acts and strategies often emphasize ,partnership principle”. Regional Development Law stresses the importance of partnership principle - cooperation between public administration institutions, international institutions, planning regions, municipalities, NGOs and entrepreneurs. Thus regulatory framework assigns different roles to NGOs.

The results of empirical study however alert that often there are difficulties in drawing a clear line between various interest groups thus it causes a challenge in trying to look at environmental NGOs, activist groups and environmental activists on one side and other target groups or actors on the other side. Specific target groups or interest groups are often used when discussing specific environmental issues and describing positions of various actors. 
Most common categories are government institutions (national, local), businesses, media etc. NGOs themselves would often split target groups into smaller ones and map specific actors along with their power - that is a common approach during planning of certain activities or NGO campaigns.

An issue worth mentioning here is that there are people and groups with so called 'double identities' i.e. representatives of businesses or public administration are joining NGOs or forming NGOs themselves to undertake certain activities. In some cases these 'double identities' can be natural i.e. an public official might also be an active citizen in his or her town and take part in a public hearing organised as part of environmental impact assessment process. For example, during several public hearing meetings about proposed new territorial plan of Jürmala that took place in January of 2011 in Jūrmala town, also several publicly wellknown politicians, officials and businessmen participated there and expressed their opinions. Within civil society this is to be seen as normal development when in different occasions one person can play different roles i.e. a person can be environmental activist, but at the same time it can also a consumer, parent, employee etc.

However there are cases when public authorities, local governments or businesses get involved in establishing NGOs and pursue some of their interests through these types of organisations. These activities can be motived both by some financial opportunities or benefits i.e. in situations when public grant money is available to NGOs, but not to public institutions or businesses, then these institutions might be interested in establishing and NGO that would formally fulfil the role of a project partner. Another reason for representatives of other target groups to establish an NGO might also be related to gaining a platform for defending their interests because NGOs are widely recognized as actors or representatives of public whose opinion should be taken into account. If quantitative research methods would be applied in the research, it would not possible to make a distinction between genuine NGOs and those that are of formal nature and serve business interests for example. Thus using of qualitative research methods are fully justified here.

Further author reviews general institutional system supporting public participation in environmental issues in Latvia i.e. both public participation opportunities that are ensured by national legislation as well as institutions that facilitate participation. Still only major aspects are mentioned here. Environmental Protection Law stipulates that "When developing a policy planning document and draft regulatory enactments, the developer shall evaluate in the annotation of the planning document or draft regulatory enactment the impact thereof on sustainable development and the environment. The strategic environmental impact assessment shall be performed for draft policy planning documents if it has been specified in the regulatory enactments regulating the environmental impact assessment." [13] Also other environmental acts and regulations lay down number of requirements with regard to public participation such as Law on Environmental Impact Assessment, Law on Pollution etc.

When it comes to institutional structures, Environmental Protection Law also defines the role of Environmental Consultative Council (ECC) - that is a council consisting of 20 environmental NGOs that wish to contribute to environmental policy making through identifying problematic issues, taking part in policy planning and evaluation of implementation. The Law [13] states that "The Ministry of Environment shall financially ensure the operation of the Environmental Consultative Council, as well as co-operate with the Environmental Consultative Council, by submitting drafts of regulatory enactments regarding the environment for discussion and the submission of proposals and shall be involved in the preparation of documents, which are associated with the environment." Also Aarhus Convention III National Implementation Report emphasizes the importance of Environmental Consultative Council stating that „To promote cooperation between public authorities and public, the ECC was established, which is comprised of representatives of 20 
NGOs; NGOs are also represented, e.g. in the Councils of Specially Protected Nature Territories, Agricultural and Environmental Protection, Forest Consulting, River Basin Management and Radiation Safety, as well as in the Biologic Safety Coordination Centre." Thus the institutional structures are seen as crucial in facilitating public participation - both representatives of environmental NGOs and public administration have acknowledged that during interviews.

As next author seeks to find answers to questions on what is the role that environmental NGOs and activist groups play in environmental governance looking at various cycles of environmental governance - issue identification, policy planning, implementation and monitoring. Looking from legal point of view environmental governance in Latvia is regulated by Environmental Protection Law. This Law states that the goal of it is to ensure the preservation and recovery of the quality of the environment, as well as the sustainable utilisation of natural resources. Does public participation and NGO involvement help achieving goals of environmental governance? Further author also assesses whether there are significant differences in contributions between officially registered NGOs and informal activist groups in the context of environmental governance.

In the stage of issue identification both environmental NGOs and activist groups play significant role. Environmental NGOs are providing feed-back to implementation of various environmental regulations, identify gaps in the system and alert other actors about issues. Participation structures such as ECC, advisory boards or working groups facilitate NGO involvement, provide certain platform and allow regular interaction with Ministry of Environment and its subordinated institutions, as well as other line ministries. Activities of environmental NGOs are not always bringing immediate or visible results. There have been tireless efforts by some nature protection NGOs to raise issues about sustainability of forest management or preservation of natural habitats in agricultural areas however those have not resulted in substantial change in the policy implementation. At the same time activist groups can expose some issues. For instance big clean-up actions have helped to foster public discussion about waste management issues and packaging system or fierce protests against building of large-scale pig farms have sparked debates about precautionary measures and environmental standards, as well as opened debate among other actors on how much public participation results should be taken into account and who is entitled to participate.

Another example of role of environmental activism is the campaign on creation of specially protected nature area in Grey Dunes in Pāvilosta. The group of local activists ensured an indefatigable campaign involving many other actors and trying various creative approaches to attention of the public, public officials and celebrities to the natural habitat of that particular grey dune through organising clean-up actions, exhibition, media events, submitting expert statements, organising expert visits and even organising a concert. As a result the Cabinet of Ministers approved the status of that area to be a natural reserve. This is an example when environmental activism has resulted in a substantial impact in the context of environmental governance.

In the stage of policy planning and looking for solutions mostly environmental NGOs play role by providing comments to draft legislation, reports and policy documents. On one hand this stage can be seen more as a routine work i.e. ECC prepares submissions and comments on various documents prepared by Ministry of Environment or other ministries. However it has to be noted that there are 20 environmental NGOs in the EEC and less than half of them are active in environmental policy work. Thus there are actually only handful of environmental NGOs that regularly follow environmental policy and its implementation. This work is mostly voluntary. Lack of capacity often prevents NGOs to look to environmental governance in a more strategic way. Representatives of environmental NGOs have pointed out on number of occasions and during interviews that sometimes they feel they are 
"extinguishing fire" i.e. preparing comments and opinions on papers that are open for comments and try to meet deadlines instead of looking to issues from more strategic point of view. As for activist groups, their involvement is rather poor in this stage. Even though some activist groups might fierce-fully oppose building of pig farms in their neighbourhood and organise protest actions, they might not show any interest in amending legislation to have stricter rules and regulations.

When it comes to describing NGO role in implementation of environmental regulations, the State Administration System Law states that "public authorities have the right to transfer certain tasks, along with allocated financing to NGOs". For example Engure Lake Nature Park is managed by an NGO [9]. Similarly environmental NGOs are involved in development of nature protection plans, as well as in working groups for development of policy documents an regulatory enactments" [9]. In the stage of implementation NGOs and activists can also act as partners to state environmental institutions. For instance State Environmental Service may involve public environmental inspectors - persons authorised by the State Environmental Service in environmental control. In 2008 around 145 public environmental inspectors participated in inspector's training, whereas in 2009 - there were 60 persons. These public inspectors often are linked to environmental NGOs or are seen as activists concerned about preservation of quality of environment and their field of work has often been into controlling and preventing illegal angling and use of motorised vehicles in coastal protected strip area.

Situation however is slightly different with environmental monitoring. According to Environmental Protection Law „The purpose of environmental monitoring shall be to specify the state of the environment, to evaluate the tendencies and perspective, to develop environmental policy measures and to evaluate the usefulness and efficiency of the previous measures". Further the EPL mentions that "Environmental monitoring shall be organised and performed by the State and local government authorities, and merchants in accordance with the requirements of the regulatory enactments regarding the environment". Thus environmental NGOs are not explicitly considered as important stakeholder in this part of cycle of environmental governance unless they would be contracted to do certain job. Environmental monitoring is considered to be primarily a function of a state. Still there are also some exceptions and some environmental NGOs are maintaining data basis and systematically collecting monitoring data. For example society "Latvijas Ezeri" ("Latvian Lakes") regularly collects data about state of environment of various lakes and maintains a data-base.

\section{Conclusions}

Author concludes that environmental governance in Latvia can be characterised as participatory. Public participation opportunities and NGO involvement are possible in all stages of environmental governance and NGOs and activist groups make use of those opportunities. Nonetheless limited NGO capacity can be a significant obstacle in providing continuous input and contribution to environmental governance.

When defining the role that NGOs and activist groups play, there are some differences between those groups. Although activist groups often are seen by other actors as the ones denying everything and eternal opponents, their activities can actually contribute to environmental governance in a meaningful way, though sometimes indirectly rather than directly. Thus activist groups should not be overlooked in their role in environmental governance. Environmental activism is more likely to play role in problem identification stage and providing feed-back to implementation of national policies and legal acts. Sometimes activist groups can bring issues into political agenda and thus provide platform for other actors, including environmental NGOs to step in and through participatory approach discuss possible solutions. 
On other hand institutionalised public participation carried out by environmental NGOs is crucial in all three stages of environmental governance, including proposing solutions and planning policies. Official environmental NGOs are also more likely to be seen also as partners to government institutions, more reliable as a source of information or expertise and NGOs can provide support when stricter regulations need to be approved or helping with expert knowledge and provide feed-back about implementation of certain environmental regulations. In short environmental NGOs are seen as more reliable counterparts versus activist groups whose involvement is somewhat more ad-hoc.

An institutional system facilitates public participation i.e. there might be participation opportunities provided by national legislation but without structures in place, they might not be utilised. For example the functioning of Environmental Consultative Council composed of 20 environmental NGOs is outlined in the Environmental Protection Law and it facilitates involvement of environmental NGOs in environmental policy making. Similarly also specific requirements laid down in national legislation about certain forms of public participation facilitate public involvement i.e. a requirement to organise public hearing meetings is something that mobilises NGOs and public at large to provide feedback about environmental impacts of certain investment project or policy paper.

\section{References}

1. Davidson, D.J., Frickel S. Understanding Environmental Governance: A Critical Review. Organization Environment 2004 17, p.471-492

2. Carmin, J. NGO capacity and environmental governance in Central and Eastern Europe. Acta Politica, Volume 45, 1/2, p.183-202

3. Young, O.R.. Natural Resources and the state: The political economy of resource management. University of California Press, 1981

4. Gramberger, M. Citizens as Partners. OECD Handbook on Information, Consultation and Public Participation in Policy-Making. 2001, p.166

5. Philips S. NGO's crowd out government in Haiti. Newsworks, February 10, 2011. Available at: http://www.newsworks.org/index.php/local/item/12754-ngos-crowd-out-government-in-haiti

6. Lursoft data base of societies and foundations (viewed on March 1, 2011). Available at: http://www.lursoft.lv/lursoft-statistika/Sabiedrisko-organizaciju-to-apvienibu-biedribu-un-nodibinajumusadalijums-pa-veidiem\&id=66

7. Civic Alliance - Latvia. Public participation. Available at: http://www.nvo.lv/recourse. php?lang=en\&id $=569$

8. The Convention on Access to Information, Public Participation in Decision-making and Access to Justice in Environmental Matters. (Passed by the Parliament of Latvia on 18 April 2002). Aarhus, 1998

9. Aarhus Convention III National Implementation Report. Ministry of Environment and Regional Development, January 2011

10. Indriksone, A. Nevalstiskās organizācijas - pašvaldību partneri attīstības plānošanā. Sabiedriskās politikas centrs PROVIDUS. 2003, p. 93 (in Latvian)

11. State Chancellery. Opportunities for Public involvement in the Policy-making Process. Available t: http://www.mk.gov.lv/en/sabiedribas-lidzdaliba/sabiedribas-lidzdaliba/

12. Jamison, A. The making of the new environmental consciousness: a comparative study of environmental movements in Sweden, Denmark and the Netherlands. Edinburgh University Press. 1990, p.216

13. Environmental Protection Law, 2006 (with amendments) 